Check for updates

Cite this: RSC Adv., 2017, 7, 18569

Received 16th February 2017

Accepted 21st March 2017

DOI: 10.1039/c7ra01961k

rsc.li/rsc-advances

\section{Investigation of Heck coupling on 6-bromo[2,3-d] thienopyrimidines for construction of new EGFR inhibitor lead structures $\uparrow$}

\author{
F. Bysting, $t^{a}$ S. Bugge, $\S^{a}$ E. Sundby (D) ${ }^{b}$ and B. H. Hoff (D)*a
}

With the aim of identifying new lead structures for EGFR inhibition, a study of palladium catalysed Heck coupling between $(R)$-6-bromo- $N$-(1-phenylethyl)thieno[2,3-d]pyrimidin-4-amine and various acrylates was performed. The Heck coupling was highly dependent on type of catalyst, solvent, base type and the use of tetrabutylammonium chloride as additive. The products were stable in the dark, but underwent trans-cis isomerization upon exposure to light. Kinase profiling indicate that acrylates grafted on the $[2,3-d]$ thienopyrimidines is an attractive scaffold for identification of potent and highly selective EGFR inhibitors.

\section{Introduction}

The epidermal growth factor receptor tyrosine kinase (EGFR) is an attractive target in EGFR driven diseases such as non-smallcell lung cancer, ${ }^{1,2}$ EGFR positive breast cancer, $^{3}$ and in pancreatic cancer. ${ }^{4}$ Inhibition of the intracellular ATP-binding site can be achieved using properly designed small molecular structures. Scaffolds employed includes mainly quinazolines, ${ }^{5,6}$ pyrrolopyrimidines, ${ }^{7-11}$ and furopyrimidines. ${ }^{12,13}$ Additionally, our laboratory and others ${ }^{14,15}$ have also identified potent thienopyrimidine based EGFR inhibitors (Fig. 1).

One drawback of some of the previously designed structures is the two carbon-based aromatic rings, which increases crystallinity, lowers solubility and in general could lead to a higher toxicity in vivo. ${ }^{17}$ In an attempt to substitute the carbon based
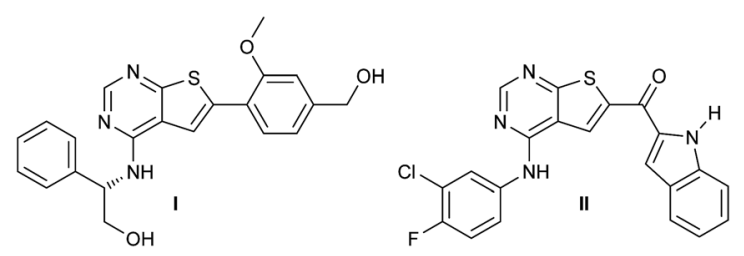

Fig. 1 Structure of potent thienopyrimidine based inhibitors I ${ }^{16}$ and II. ${ }^{15}$

${ }^{a}$ Department of Chemistry, Faculty of Natural Sciences and Technology, Norwegian University of Science and Technology (NTNU), NO-7491 Trondheim, Norway. E-mail: Bard.Helge.Hoff@chem.ntnu.no

${ }^{b}$ Department of Materials Science and Engineering, Norwegian University of Science and Technology (NTNU), NO-7491 Trondheim, Norway

$\dagger$ Electronic supplementary information (ESI) available: Contains kinase screen data and molecular docking and dynamics figures. See DOI: 10.1039/c7ra01961k \$ Current address: Pronova BioPharma Norge AS, NO-3202 Sandeford, Norway. $\S$ Current address: Dynea AS, Svelleveien 33, NO-2004 Lillestrøm, Norway. aromatic ring at the thiophene moiety (C-6), we envisioned that alkenes could be employed. This moiety was planned inserted by a palladium catalysed Heck coupling. However, the Heck reaction is extremely sensitive to the choice of catalyst, cocatalyst, solvent, reaction temperature etc. ${ }^{18}$ Therefore, each new Heck reaction often needs careful optimisation of the reaction conditions. Herein, our efforts to identify new EGFR lead structures, and an investigation of the Heck coupling is described. The chemical part of the study has evaluated the effect of catalyst/ligand systems, solvent, base and additives, and also describes the challenges encountered during handling of these materials. Finally, the initial evaluation of the new structures as kinase inhibitors is presented.

\section{Result and discussion}

\section{Investigation of the Heck reaction}

As a starting point for the study of the Heck-reaction, $(R)-6$ bromo- $N$-(1-phenylethyl)thieno[2,3- $d$ ] pyrimidin-4-amine (1) and methyl acrylate were employed as coupling partners, see Scheme 1. Compound $\mathbf{1}$ was selected since it is a previously identified low molecular weight structure with nanomolar EGFR potency. ${ }^{19}$

First, six catalysts systems were evaluated, namely palladium on carbon $(\mathrm{Pd} / \mathrm{C})$, palladium(II) diacetate $\left(\mathrm{Pd}(\mathrm{OAc})_{2}\right)$, tetrakis(triphenylphosphine)palladium $(0) \quad\left(\mathrm{Pd}\left(\mathrm{PPh}_{3}\right)_{4}\right), \quad$ bis(tri-tert-butylphosphine)palladium $(0)\left(\mathrm{Pd}\left(t-\mathrm{Bu}_{3} \mathrm{P}\right)_{2}\right),\left[1,1^{\prime}\right.$-bis(di-tert-butylphosphino) ferrocene]-dichloropalladium(II) $\left(\mathrm{PdCl}_{2}(\mathrm{dtbpf})\right)$ and Xphos $\mathrm{Pd}$

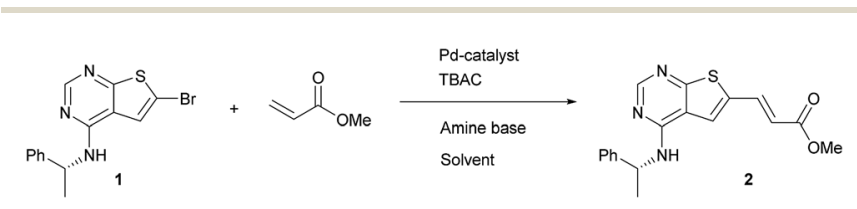

Scheme 1 Model system for investigation of the Heck reaction. 
$3^{\text {rd }}$ generation catalyst, all in 2 mol\%. Other conditions adapted from Murray et $a .^{20}$ included tetrabutylammonium chloride (TBAC), $N, N$-dimethylacetamide (DMAc) as solvent and $N, N$ dicyclohexylmethylamine $\left(\mathrm{Cy}_{2} \mathrm{NMe}\right)$ as base. A ten-fold excess of methyl acrylate was employed. The reaction progress as followed by ${ }^{1} \mathrm{H}$ NMR spectroscopy is shown in Fig. 2 .

Clear differences were seen in rate for the different catalysts, with $\mathrm{Pd}\left(t-\mathrm{Bu}_{3} \mathrm{P}\right)_{2}$ being the most effective system. The reaction catalysed by palladium diacetate showed a high initial rate, however, conversion ceased around $80 \%$, possibly due to catalyst precipitation. On the other hand, the ferrocene based catalyst $\mathrm{PdCl}_{2}(\mathrm{dtbpf})$ showed lower initial rate, but managed to catalyse the reaction fully within 24 hours. The cross-coupling mediated by $\mathrm{Pd} / \mathrm{C}$ had a slow onset, but attained $78 \%$ conversion within 24 hours, whereas the use of Xphos Pd G3 and $\mathrm{Pd}\left(\mathrm{PPh}_{3}\right)_{4}$ worked poorly under these conditions. Overall, $\operatorname{Pd}\left(t-\mathrm{Bu}_{3} \mathrm{P}\right)_{2}$ appeared to be the catalyst of choice. One byproduct was seen in these reaction, namely the cis-isomer 3 . This was proved by the light induced interconversion of these compounds (see next Section), the ${ }^{1} \mathrm{H}$ NMR coupling constants, MS analysis, and that reduction of the isomeric mixture yielded only compound $\mathbf{4}$, see Scheme 2 .

Following the initial catalyst selection, the effect of the amount of methyl acrylate on conversion was investigated using 2-, 4-, and a 6-fold excess, see Table 1.

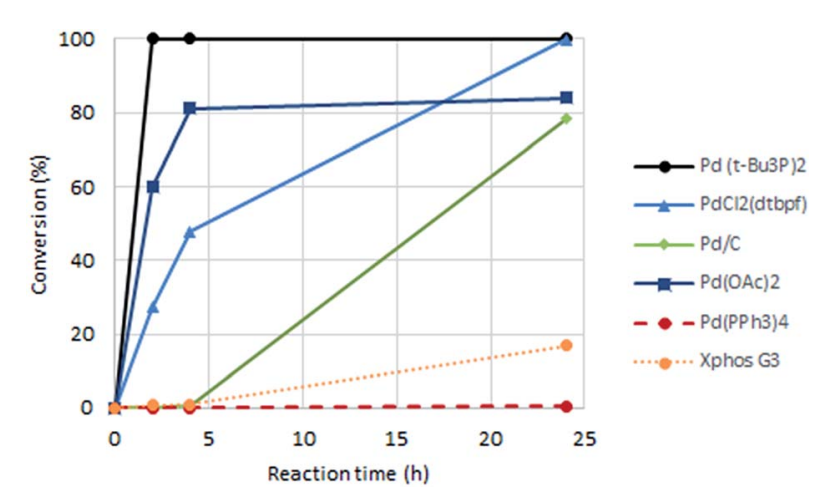

Fig. 2 Effect of palladium catalyst on degree of conversion of 1 to the Heck product acrylate 2 .

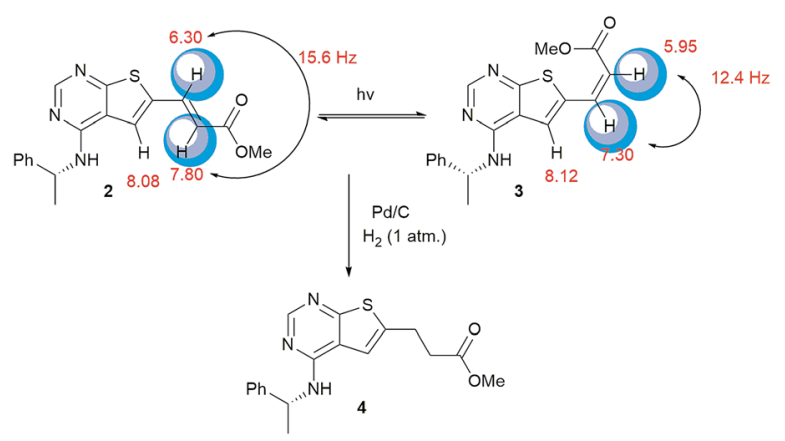

Scheme 2 When exposed to light compound 2 converts to compound 3. Reduction of these compounds gave the saturated derivative 4
The amount of methyl acrylate used in the reaction had a dramatic effect on degree of conversion. For the coupling with two equivalents $86 \%$ conversion was obtained in 24 hours, while with four equivalents full conversion was obtained in 24 hours. In contrast the Heck coupling employing 6 equivalents of methyl acrylate went to completion in only two hours. The trans/ cis ratio of the product varied without any apparent trend. When the same reaction was run in the absence of inert atmosphere the reaction ceased at $8 \%$ conversion.

The choice of solvent can have a dramatic effect on rate in such coupling reactions. Therefore, the use of eight additional solvents was evaluated. The degree of conversion after 4 hours is compared in Table 2. Although couplings in all these solvents were slower than in DMAc, reactions in 1,2-dimethoxyethane (DME), 2-methyltetrahydrofuran (2-MeTHF), 1,4-dioxane, toluene and THF reached full conversion in 24 hours. The initial rate in both acetonitrile and neat methyl acrylate was comparable to that of the best solvent systems. However, in these medias the conversion ceased around 60\%, indicating catalyst decomposition. The reactions in ethanol and tert-butyl methyl ether (TBME) also halted, but at even lower degree of conversion. Employing trimethylamine as both a base and a solvent lead to a slow reaction, which only reached $9 \%$ conversion in 4 hours. The isomeric ratio varied from $9 / 1$ to $24 / 1$ without any apparent trend with respect to solvent polarity.

Often, the Heck reaction is sensitive to the nature of cocatalysts and the base. Therefore, additional experiments were

Table 1 Effect of methyl acrylate equivalents on conversion and trans/ cis ratio. The reaction was performed at $80{ }^{\circ} \mathrm{C}$ using $\mathrm{Pd}\left(t-\mathrm{Bu}_{3} \mathrm{P}\right)_{2}$ as catalyst, DMAc as solvent, 0.1 equivalents of tetrabutylammonium chloride (TBAC), and $\mathrm{N}, \mathrm{N}$-dicyclohexylmethylamine as base

\begin{tabular}{llllll}
\hline Equiv. & Time & Conv. $^{a}$ & $\mathbf{2}^{a}$ & $\mathbf{3}^{a}$ & Ratio 2/3 \\
\hline 2 & 24 & 86 & 80 & 6 & 14 \\
4 & 24 & $>99$ & 99 & 1 & 71 \\
6 & 2 & $>99$ & 90 & 7 & 12
\end{tabular}

${ }^{a}$ Determined by ${ }^{1} \mathrm{H}$ NMR spectroscopy.

Table 2 Effect of solvent on rate of conversion and isomeric ratio in Heck coupling using $\mathrm{Pd}\left(t-\mathrm{Bu}_{3} \mathrm{P}\right)_{2}$, tetrabutylammonium chloride (TBAC), and $N, N$-dicyclohexylmethylamine as base. A ten-fold excess of methyl acrylate was employed

\begin{tabular}{llllll}
\hline Entry & Solvent & Conv. $^{a}(\%) \mathbf{h}$ & $\mathbf{2}^{a}$ & $\mathbf{3}^{a}$ & Ratio 2/3 \\
\hline 2 & 2-MeTHF & 97 & 93 & 5 & 20 \\
3 & DME & 95 & 91 & 4 & 22 \\
4 & Toluene & 80 & 72 & 8 & 9 \\
5 & THF & 74 & 69 & 5 & 14 \\
6 & ACN & 60 & 58 & 2 & 24 \\
7 & Methyl acrylate $^{b}$ & 60 & 57 & 3 & 20 \\
8 & EtOH $_{9}^{c}$ & 32 & 29 & 3 & 10 \\
10 & NEt $_{3}{ }^{2}$ & 9 & 9 & 0 & $d$ \\
& TBME $^{2}$ & 5 & 5 & 0 & $d$
\end{tabular}

${ }^{a}$ Determined by ${ }^{1} \mathrm{H}$ NMR spectroscopy. ${ }^{b} 40$-fold excess of methyl acrylate. ${ }^{c} N, N$-Dicyclohexylmethylamine was not used. ${ }^{d}$ Ratio could not be determined due to low conversion. 
Table 3 Effect of phase transfer catalyst and a change in base on rate of conversion and isomeric ratio in $\mathrm{Heck}_{\mathrm{c}}$ coupling using $\mathrm{Pd}\left(t-\mathrm{Bu} 3 \mathrm{P}_{2}\right.$. $\mathrm{A}$ tenfold excess of methyl acrylate was employed

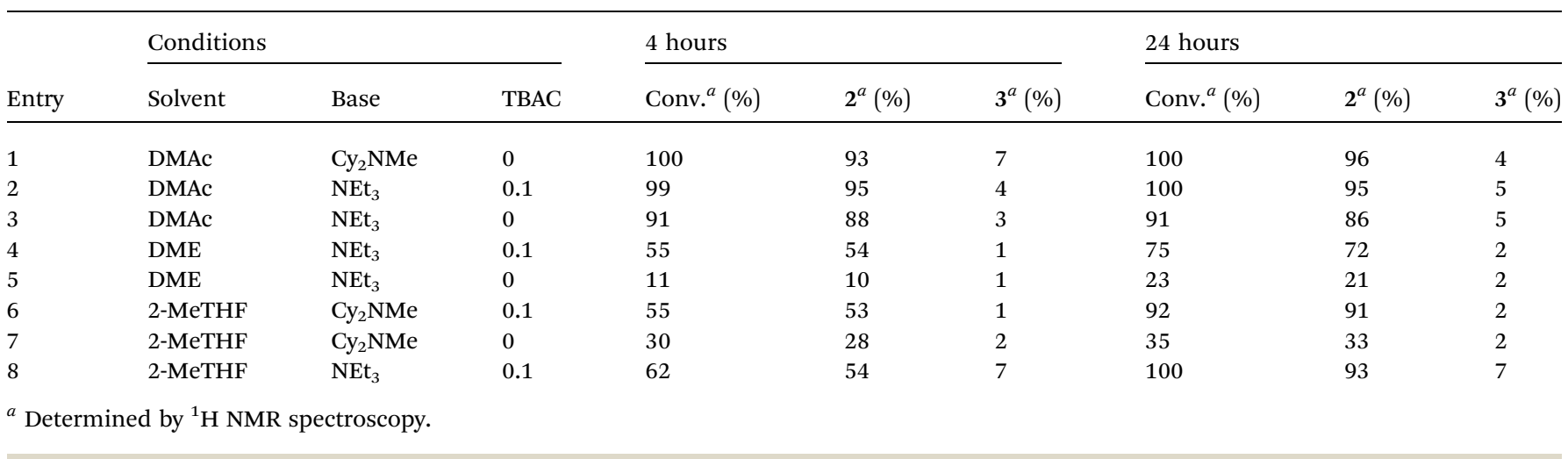

performed where TBAC was omitted and trimethylamine was used instead of $\mathrm{Cy}_{2} \mathrm{NMe}$, see Table 3 .

When performing the reaction in DMAc with $\mathrm{Cy}_{2} \mathrm{NMe}$ as base in the absence of the phase transfer catalyst (entry 1 ), no major change in conversion was noted. However, in experiments using trimethylamine as base in DMAc and DME, lower conversion was observed without TBAC. This was also the case using 2-MeTHF as solvent in combination with $\mathrm{Cy}_{2} \mathrm{NMe}$ as base. Obviously, the TBAC additive improves the reaction rate of the Heck reaction, and especially so in solvents of low polarity. The role of the phase transfer catalyst is somewhat unclear, but it has been suggested that the chloride anion play a role as a supporting ligand in generating the active $\operatorname{Pd}(0)$ complex. ${ }^{21-23}$ An alternative explanation proposed is that the phase-transfer catalyst brings about an encapsulation of $\operatorname{Pd}(0)$, preventing formation of palladium black. ${ }^{24,25}$ As the initial investigations indicated that the Heck coupling was fairly robust, the reaction was scaled starting with 1 gram of compound 1 using DMAc, triethylamine and TBAC and reacting for 24 hours. Full conversion was obtained and a trans/cis ratio of $15 / 1$ was noticed. As a high trans/cis ratio was targeted, the purity of the material was improved by precipitation from dichloromethane followed by re- crystallization from the same solvent. This lead to a trans/cis ratio of 32 ( $97 \%$ by HPLC), however in only $27 \%$ yield (Table 4 , entry 1). We were unable to purify similar prepared materials efficiently using silica-gel chromatography or preparative HPLC.

Four other Heck reactions were attempted in $0.2 \mathrm{~g}$ scale (entries 2-5). Of these, conversion to the 2-methoxyethyl ester 5 (entry 2) proceeded very efficiently, but anyhow the isolated yield was mediocre due to a difficult separation of the cis isomer, the presence of polymers and most likely transcis isomerization during the purification. The process to compound 6 (entry 3 ) was run for 24 hours, but was observed to stop already at 4 hours. Also disappointingly, the coupling with acrylamide (entry 4) failed completely. As Heck coupling with acrylamides have been performed with other Pd-catalyst systems, ${ }^{26,27}$ this result can most likely be ascribed to the delicate nature of this coupling method. In contrast, $N, N$ dimethylacrylamide (Table 4, entry 5) was well tolerated as substrate.

As compound 7 could not be made by the Heck reaction, it was formed by ammonolysis of 2 (Scheme 3 ). This process gave after crystallization $30 \mathrm{mg}$ of compound 7 , but the trans/cis ratio was $5 / 1$.

Table 4 Preparative Heck-couplings to produce trans derivatives 2 and $5-8$ by reacting for 24 hours at $80^{\circ} \mathrm{C}$

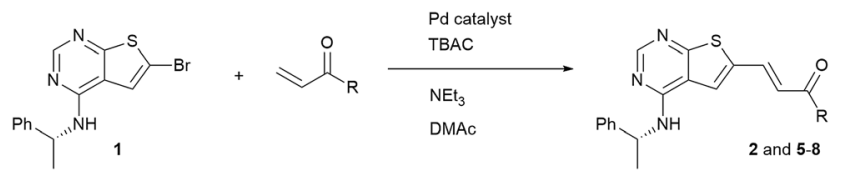

\begin{tabular}{|c|c|c|c|c|c|c|}
\hline Entry & $\mathrm{R}$ & Conv. $^{a}(\%)$ & Purity $^{b}$ & Ratio trans/cis ${ }^{c}$ & Yield (\%) & Product \\
\hline 1 & OMe & $>99$ & 97 & $>30$ & $27^{d}$ & 2 \\
\hline 2 & $\mathrm{OCH}_{2} \mathrm{CH}_{2} \mathrm{OMe}$ & $>99$ & 96 & 21 & $39^{e}$ & 5 \\
\hline 4 & $\mathrm{NH}_{2}$ & 0 & - & - & - & 7 \\
\hline 5 & $\mathrm{NMe}_{2}$ & 92 & 99 & $>30$ & $27^{d}$ & 8 \\
\hline
\end{tabular}

${ }^{a}$ Conversion after 24 hours determined by ${ }^{1} \mathrm{H}$ NMR spectroscopy. ${ }^{b}$ Purity (area\%) determined by RP-HPLC. ${ }^{c}$ Isomer ratio by ${ }^{1} \mathrm{H}$ NMR spectroscopy.

${ }^{d}$ Purified by crystallization. ${ }^{e}$ Purified by silica gel-column chromatography. 
<smiles>COC(=O)/C=C/c1cc2c(NC(C)c3ccccc3)ncnc2s1</smiles>
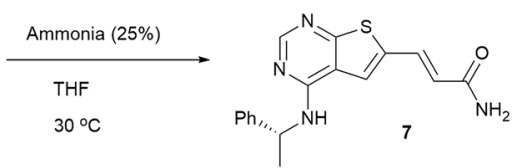

Scheme 3 Ammonolysis of compound 2.

\section{Stability of the product}

As judged from ${ }^{1} \mathrm{H}$ NMR spectroscopy the reaction proceeded with a low level of cis-configurated product. However, upon final purification, HPLC analysis revealed this product to be difficult to remove completely. Apparently, the isomerization process occurred during handling. Fig. 3 shows ${ }^{1}$ H NMR of the same NMR sample prior and after four day storage in daylight.

To shed light on the isomerization process, stability testing was performed in various solvents in the dark and at the lab bench exposed to light. The levels of the main impurity as analysed by HPLC (area\%) is shown in Table 5 .

When stored in the dark no major change of the level of the cis-isomer 3 was detected (entries 1-4). However, in benchtop daylight a steady rise in the level of $c i s-3$ was seen in all solvents except in water. Compounds 5-8 were submitted to similar experiments in acetonitrile and exposed to daylight. After 48 hours the level of the cis impurity increased to a level of $23-37 \%$. This clearly shows that such materials must be handled with
A

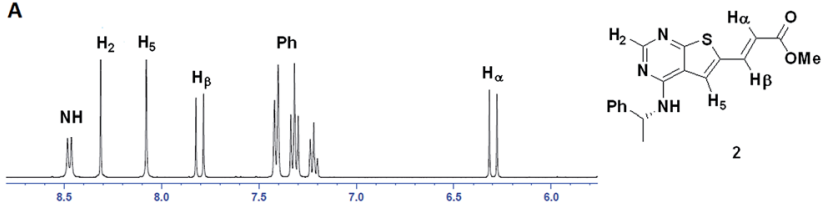

B

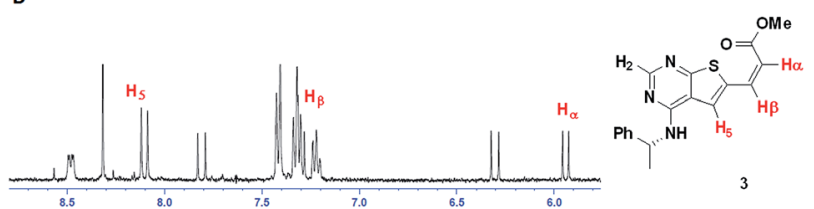

Fig. $3{ }^{1} \mathrm{H}$ NMR before (A) and after (B) light exposure of compound 2 .

Table 5 Level of cis-3 in purified material 2 as analysed by HPLC following exposure to solvent and light over 6 days

\begin{tabular}{|c|c|c|c|c|c|}
\hline \multirow[b]{2}{*}{ Entry } & \multirow[b]{2}{*}{ Solvent } & \multirow[b]{2}{*}{ Conditions } & \multicolumn{3}{|c|}{$\begin{array}{l}\text { Amount of } c i s-3^{a} \\
(\text { area\%) }\end{array}$} \\
\hline & & & $0 \mathrm{~h}$ & $48 \mathrm{~h}$ & $144 \mathrm{~h}$ \\
\hline 1 & Acetonitrile & Dark & 3 & 3 & 4 \\
\hline 2 & THF & Dark & 2 & 2 & 2 \\
\hline 3 & THF/water (1: 1 vol\%) & Dark & 2 & 2 & 2 \\
\hline 4 & Water & Dark & 2 & 2 & 2 \\
\hline 5 & Acetonitrile & Light & 3 & 16 & 24 \\
\hline 6 & THF & Light & 2 & 14 & 22 \\
\hline 7 & THF/water (1: 1 vol\%) & Light & 2 & 13 & 20 \\
\hline 8 & Water & Light & 2 & 2 & 5 \\
\hline
\end{tabular}

${ }^{a}$ Determined by RP-HPLC. extreme care and should be protected from light during production, purification and storage. In retrospect, these Heckcouplings could benefit from some of the solid supported catalyst systems developed..$^{28-30}$ This would ease purification, probably lower the degree of trans-cis isomerisation and amount of palladium in the end-product.

\section{EGFR kinase inhibitory properties}

Compounds $\mathbf{2}$ and 4-8 were profiled in an epidermal growth factor receptor tyrosine kinase (EGFR) assay at $100 \mathrm{nM}$ concentration using an ATP concentration equal to $K_{\mathrm{M}}$, and benchmarked with the corresponding phenyl substituted analogues 9 and 10, see Table 6 .

All compounds had promising inhibitory activity. Interestingly, the unsaturated compound 2 was more potent than the saturated analogue $\mathbf{4}$. The 2-methoxyethyl ester $\mathbf{5}$, and especially the 2-hydroxyethyl ester 6 showed a further improvement in

Table 6 EGFR profiling of compounds 2, 5-8 and reference materials

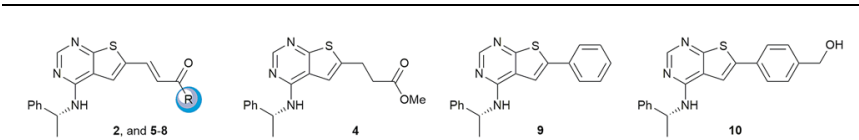

\begin{tabular}{llllll}
\hline Entry & Comp. & $\mathrm{R}$ & Inhi. $^{a}(\%)$ & $\mathrm{IC}_{50}{ }^{b}(\mathrm{nM})$ & $\mathrm{Mp}\left({ }^{\circ} \mathrm{C}\right)$ \\
\hline 1 & $\mathbf{2}$ & $\mathrm{OMe}$ & 78 & - & $98-100$ \\
2 & $\mathbf{4}$ & $c$ & 49 & - & Oil \\
3 & $\mathbf{5}$ & $\mathrm{OCH}_{2} \mathrm{CH}_{2} \mathrm{OMe}$ & 85 & - & Oil \\
4 & $\mathbf{6}$ & $\mathrm{OCH}_{2} \mathrm{CH}_{2} \mathrm{OH}$ & 94 & $7.0 \pm 0.3$ & $144-145$ \\
5 & 7 & $\mathrm{NH}_{2}$ & 90 & $13 \pm 0.2$ & $246-251$ \\
6 & $\mathbf{8}$ & $\mathrm{NMe}_{2}$ & 73 & - & $154-155$ \\
7 & $\mathbf{9}$ & $c$ & 58 & $58 \pm 2^{d}$ & $171-173^{d}$ \\
8 & $\mathbf{1 0}$ & $c$ & 86 & $7 \pm 1^{d}$ & $215-217^{d}$ \\
9 & Erlotinib & & 102 & $0.4 \pm 0.1$ & $159-160^{e}$
\end{tabular}

${ }^{a}$ Mean value of two measurements at $100 \mathrm{nM}$ concentration. ${ }^{b}$ Mean value of two titration curves (20 data points) and standard deviation. ${ }^{c}$ See structure above. ${ }^{d}$ Data is taken from Bugge et al. ${ }^{16}{ }^{e}$ Data taken from Knesl et al. ${ }^{31}$

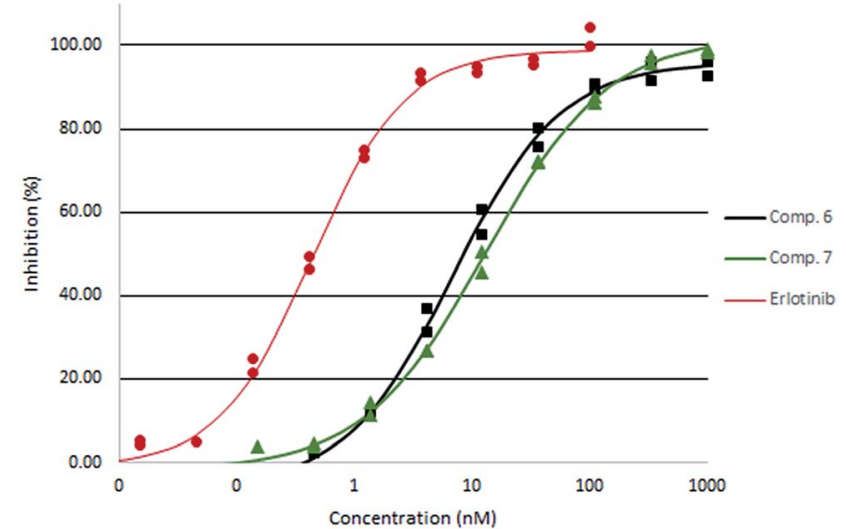

Fig. 4 EGFR IC 50 titration curves of compound 6 (squares) and 7 (triangles) compared with Erlotinib (circles). 
potency. For the two amides assayed the unsubstituted derivative 7 was more potent that the dimethyl analogue 8. The two most active derivatives were also assayed by $\mathrm{IC}_{50}$ titration (Fig. 4).

Compound 6 was found slightly more potent than the unsubstituted amide 7 and was equipotent with the 4-hydroxymethylphenyl substituted compound 9 . Whereas the amide 7 had a rather high melting point, the ester derivatives and the dimethyl amide $\mathbf{8}$ appears less crystalline than the phenyl analogues $\mathbf{9}$ and $\mathbf{1 0}$.

Compound 5, $\mathbf{6}$ and 7 were subjected to docking studies using the EGFR crystal structure 2J6M (wild-type EGFR). 2D interaction plot for the best docking poses and corresponding docking score energies for all compounds are shown in S1-S3 (ESI†). These poses were subsequently exposed to $10 \mathrm{~ns}$ dynamic simulations, and diagrams showing the most important ligand-protein interactions for compound $\mathbf{5}$ and $\mathbf{6}$ are shown in Fig. 5. Binding of both compounds seem to depend heavily on a hydrogen-bond interaction from methionine 793 and threonine 854 (via a water molecule bridge) as well as a cation- $\pi$ interaction between lysine 745 and the phenyl ring in the amine part of the ligand. However, no clear difference in terms of ligand-protein affinity were evident after these simulations. When evaluating the best docked poses of $\mathbf{5}$ and $\mathbf{6}$, an overlay of the two (ESI $\dagger$ ) shows

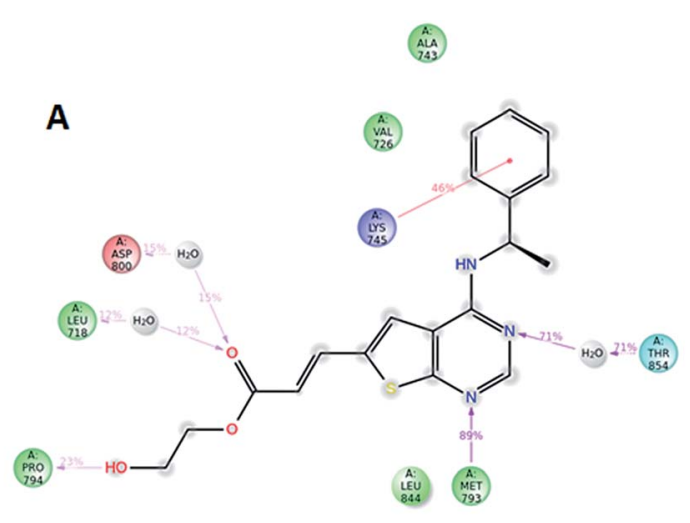

B

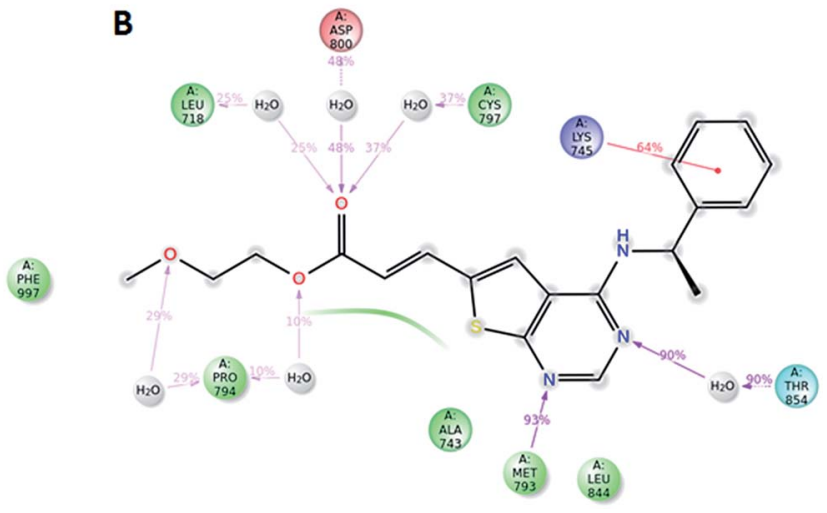

Fig. 5 Ligand-EGFR contacts for compounds 6 (A) and 5 (B) after docking and 10 ns dynamic simulation. Only those interactions are shown that occur more than $10 \%$ of the 10 ns simulation time. (For interpretation of the references to colour in this figure legend, the reader is referred to the web version of this article).

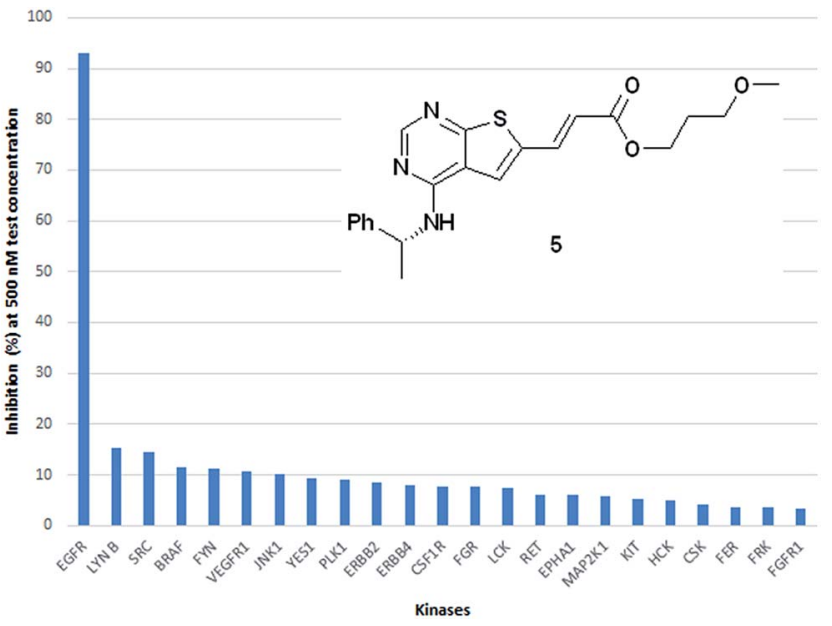

Fig. 6 Kinase profiling towards a panel of 50 additional kinase showed a high selectivity for EGFR. The main off targets and their degree of inhibition is shown.

that the only notable difference was in the alcohol and ether sidechain, which might explain the difference in docking scores (5: $-10.057 \mathrm{kcal} \mathrm{mol}^{-1}$ and 6: $-9.408 \mathrm{kcal} \mathrm{mol}^{-1}$ ). A root mean square fluctuation analysis after $10 \mathrm{~ns}$ of dynamic simulations also showed that the flexibility of these side chains was quite similar when bound to the protein (ESI†).

Potentially, these structures could be suitable as irreversible inhibitors by reaction between the $\beta$-carbon and the thiol moiety of Cysteine 797. However, the moderate increase in activity going from the saturated to the unsaturated derivatives, using one-hour incubation time indicate that this is not the case. Moreover, docking experiments show that the distance from the thiol to the $\beta$-carbon is $c a .7 \AA$, which is too distant to expect covalent binding (ESI $\dagger$ ).

As an indication of the kinase selectivity displayed by this new class of inhibitors the inhibitor 5 was assayed towards a panel of 50 additional kinases at $500 \mathrm{nM}$ test concentration. The analysis revealed a remarkable high selectivity for EGFR over all other kinases evaluated. The $\%$ inhibition towards the main off-targets are shown in Fig. 6.

\section{Experimental}

\section{General}

Compounds 1 was made in a previous study, ${ }^{16}$ while all other chemicals were from Sigma Aldrich. Silica-gel column chromatography was performed using silica gel 60A from Fluka, pore size $40-63 \mu \mathrm{m}$. Celite 545 from Fluka was also used. ${ }^{1} \mathrm{H}$ and ${ }^{13} \mathrm{C}$ NMR spectra were recorded with Bruker Avance 400 spectrometer operating at $400 \mathrm{MHz}$ and $100 \mathrm{MHz}$, respectively. Coupling constants are in hertz. HPLC (Agilent 110-Series) with a G1379A degasser, G1311A Quatpump, G1313A ALS autosampler and a G1315D Agilent detector $(230 \mathrm{~nm})$ was used to determine the purity of the synthesised compounds. Conditions: Method A:Poroshell C18 $(100 \times 4.6 \mathrm{~mm})$ column, flow rate $0.8 \mathrm{~mL} \mathrm{~min}^{-1}$, elution starting with water/ $\mathrm{CH}_{3} \mathrm{CN}(90 / 10), 5 \mathrm{~min}$ isocratic elution, then linear gradient elution for 30 min ending at $\mathrm{CH}_{3} \mathrm{CN}$ / 
water (100/0). Accurate mass determination (ESI) was performed on an Agilent G1969 TOF MS instrument equipped with a dual electrospray ion source, or EI (70 eV) using a Finnigan MAT 95 XL. Accurate mass determination in positive and negative mode was performed on a "Synapt G2-S" Q-TOF instrument from Waters. Samples were ionized by the use of an ASAP probe, no chromatography separation was used before the mass analysis. FTIR spectra were recorded on a Thermo Nicolet Avatar 330 infrared spectrophotometer. All melting points are uncorrected and measured by a Stuart automatic melting point SMP40 apparatus.

\section{Synthesis of methyl $(R, E)-3-(4-((1-p h e n y l e t h y l) a m i n o) t h i e n o$ $[2,3-d]$ pyrimidin-6-yl)acrylate (2)}

$(R)$-6-Bromo- $N$-(1-phenylethyl)thieno[2,3- $d]$-pyrimidin-4-amine (1) (1.00 g, $2.99 \mathrm{mmol})$, bis(tri-tert-butylphospine)palladium(0) (31.9 $\mathrm{mg}, 0.06 \mathrm{mmol}$ ) and tetrabutylammonium chloride (90 mg, $0.32 \mathrm{mmol}$ ) were mixed under a nitrogen atmosphere. $N, N$-Dimethylacetamide $(15 \mathrm{~mL})$, triethylamine $(0.625 \mathrm{~mL}, 4.49$ $\mathrm{mmol})$ and methyl acrylate $(1.62 \mathrm{~mL}, 18.0 \mathrm{mmol})$ were added, and the mixture was stirred at $80{ }^{\circ} \mathrm{C}$ for $24 \mathrm{~h}$. The reaction mixture was added ethyl acetate $(50 \mathrm{~mL})$ and washed with water $(4 \times 40 \mathrm{~mL})$. The organic phase was dried with brine $(50$ $\mathrm{mL}$ ), then over anhydrous $\mathrm{Na}_{2} \mathrm{SO}_{4}$, and filtered. The filtrate was concentrated under reduced pressure, resulting in a yellow oil. Repeated solvent displacement using dichloromethane resulted in $1.19 \mathrm{~g}$ of a yellow-brown solid. The crude product was washed with cold dichloromethane $(15 \mathrm{~mL})$, resulting in a less coloured solid $(0.82 \mathrm{~g})$. This was followed by crystallized from dichloromethane $(10 \mathrm{~mL})$ resulting in $270 \mathrm{mg}(0.795 \mathrm{mmol}$, $27 \%$ ) of a yellow solid; mp $98-100{ }^{\circ} \mathrm{C}$; purity (HPLC): $97 \%, t_{\mathrm{R}}=$ $23.2 \mathrm{~min} ;[\alpha]_{\mathrm{D}}^{20}=-351.2$ (c 1.01, DMSO). ${ }^{1} \mathrm{H}$ NMR $(400 \mathrm{MHz}$, DMSO- $\left.d_{6}\right): 8.48(\mathrm{~d}, J=7.8,1 \mathrm{H}, \mathrm{NH}), 8.32(\mathrm{~s}, 1 \mathrm{H}, \mathrm{H}-2), 8.08(\mathrm{~s}$, $1 \mathrm{H}, \mathrm{H}-5), 7.81$ (d, $\left.J=15.6,1 \mathrm{H}, \mathrm{H}_{\beta}\right), 7.42-7.40(\mathrm{~m}, 2 \mathrm{H}, \mathrm{Ph}), 7.34-$ $7.30(\mathrm{~m}, 2 \mathrm{H}, \mathrm{Ph}), 7.24-7.20(\mathrm{~m}, 1 \mathrm{H}, \mathrm{Ph}), 6.30(\mathrm{~d}, J=15.6,1 \mathrm{H}$, $\left.\mathrm{H}_{\alpha}\right), 5.54-5.47(\mathrm{~m}, 1 \mathrm{H}, \mathrm{CH}), 3.74\left(\mathrm{~s}, 3 \mathrm{H}, \mathrm{OCH}_{3}\right), 1.55$ (d, $J=7.0$, $\left.3 \mathrm{H}, \mathrm{CH}_{3}\right) ;{ }^{13} \mathrm{C}$ NMR $\left(100 \mathrm{MHz}, \mathrm{DMSO}-d_{6}\right): 166.1,166.0,156.0$, 155.3, 144.3, 137.4, 133.5, 128.3 (2C), 126.7, 126.1 (2C), 125.3, 118.3, 116.6, 51.7, 49.1, 22.3; IR ( $\left.\mathrm{cm}^{-1}\right): 3239$ (w, br), $1715(\mathrm{~m})$, 1574 (s), 1502 (m), 1442 (m), 1299 (s), 1264 (s), 1163 (s), 962 (m), 694 (s); HRMS (ASAP $\left.{ }^{+}, \mathrm{m} / z\right)$ : found 340.1122, calcd for $\mathrm{C}_{18} \mathrm{H}_{18} \mathrm{~N}_{3} \mathrm{O}_{2} \mathrm{~S}[\mathrm{M}+\mathrm{H}]^{+}$340.1120.

\section{Synthesis of methyl (R)-3-(4-((1-phenylethyl)amino)thieno[2,3- d]pyrimidin-6-yl)propanoate (4)}

Ethanol $(20 \mathrm{~mL})$ and $\mathrm{Pd} / \mathrm{C}(10 \%, 20 \mathrm{mg})$ were mixed and then added methyl (R,E)-3-(4-((1-phenylethyl)amino)thieno[2,3- $d]$ pyrimidin-6-yl)-acrylate (2) (193 mg, $0.570 \mathrm{mmol}$ ). Hydrogen gas was bubbled through the solution and then applied as atmosphere ( $1 \mathrm{~atm})$. The mixture was allowed to stir for $168 \mathrm{~h}$ at $20{ }^{\circ} \mathrm{C}$, with additional addition of ethanol $(10 \mathrm{~mL})$ and $\mathrm{Pd} / \mathrm{C}$ $(10 \%, 20 \mathrm{mg})$ as well as refilling of $\mathrm{H}_{2}$. The reaction mixture was filtered through celite and concentrated under reduced pressure. The crude product (183 mg) was purified by silica-gel column chromatography (ethyl acetate/n-pentane 1/1). This gave $78 \mathrm{mg}(0.229 \mathrm{mmol}, 40 \%)$ as a light yellow oil; purity $(\mathrm{HPLC})>99 \%, t_{\mathrm{R}}=21.5 \mathrm{~min} ;[\alpha]_{\mathrm{D}}^{20}=-140.5$ (c 1.03, DMSO). ${ }^{1} \mathrm{H}$
NMR (400 MHz, DMSO- $\left.d_{6}\right): 8.22(\mathrm{~s}, 1 \mathrm{H}, \mathrm{H}-2), 8.09$ (d, $J=8.0,1 \mathrm{H}$, $\mathrm{NH}$ ), 7.52 (s, 1H, H-5), 7.40-7.39 (m, 2H, Ph), 7.32-7.29 (m, 2H, $\mathrm{Ph}), 7.22-7.19(\mathrm{~m}, 1 \mathrm{H}, \mathrm{Ph}), 5.51-5.46(\mathrm{~m}, 1 \mathrm{H}, \mathrm{CH}), 3.62(\mathrm{~s}, 3 \mathrm{H}$, $\left.\mathrm{OCH}_{3}\right), 3.13\left(\mathrm{t}, J=7.1,2 \mathrm{H}, \mathrm{CH}_{2}\right), 2.76\left(\mathrm{t}, J=7.1,2 \mathrm{H}, \mathrm{CH}_{2}\right), 1.53$ $\left(\mathrm{d}, J=7.9,3 \mathrm{H}, \mathrm{CH}_{3}\right) ;{ }^{13} \mathrm{C}$ NMR $\left(100 \mathrm{MHz}, \mathrm{DMSO}-d_{6}\right): 172.1$, 165.0, 155.3, 153.2, 144.8, 139.2, 128.2 (2C), 126.6, 126.0 (2C), 116.6, 116.2, 51.5, 48.9, 34.3, 25.5, 22.5; IR $\left(\mathrm{cm}^{-1}\right): 3280$ (w, br), 2975 (w, br), 1734 (s), 1578 (s), 1514 (s), 1436 (m), 1351 (m), 1203 (m), 1169 (m), $1024(\mathrm{~m}), 866$ (m), 698 (s); HRMS (ASAP $\left.{ }^{+}, \mathrm{m} / \mathrm{z}\right)$ : found 342.1274, calcd for $\mathrm{C}_{18} \mathrm{H}_{20} \mathrm{~N}_{3} \mathrm{O}_{2} \mathrm{~S}[\mathrm{M}+\mathrm{H}]^{+} 342.1276$.

\section{2-Methoxyethyl (R,E)-3-(4-((1-phenylethyl)amino)thieno[2,3-d] pyrimidin-6-yl)acrylate (5)}

$(R)$-6-Bromo- $N$-(1-phenylethyl)thieno[2,3- $d]$-pyrimidin-4-amine (1) (208 mg, $0.622 \mathrm{mmol}$ ) and bis(tri-tert-butylphospine)palla$\operatorname{dium}(0)(8.0 \mathrm{mg}, 0.015 \mathrm{mmol})$ and tetrabutylammonium chloride (17 mg, $0.06 \mathrm{mmol}$ ) were mixed under a nitrogen atmosphere. $N, N$-Dimethylacetamide $(3 \mathrm{~mL})$, triethylamine $(0.125 \mathrm{~mL}, 0.9 \mathrm{mmol})$ and 2-methoxyethyl acrylate $(0.80 \mathrm{~mL}$, $6.22 \mathrm{mmol}$ ) were added, and the mixture was stirred at $80{ }^{\circ} \mathrm{C}$ for $24 \mathrm{~h}$. The reaction mixture was added ethyl acetate $(20 \mathrm{~mL})$ and washed with water $(3 \times 15 \mathrm{~mL})$. The organic phase was dried with brine $(20 \mathrm{~mL})$, then over anhydrous $\mathrm{Na}_{2} \mathrm{SO}_{4}$, and filtered. The filtrate was concentrated under reduced pressure, resulting in $172 \mathrm{mg}$ of the crude product. The material (151 mg, $0.40 \mathrm{mmol}$ ) was purified by silica-gel column chromatography (diethyl ether, $\left.R_{\mathrm{f}}=0.55\right)$ gave $93 \mathrm{mg}(0.243 \mathrm{mmol}$, $39 \%$ ) of a yellow oil; purity (HPLC): $96 \%, t_{\mathrm{R}}=22.8 \mathrm{~min} ;[\alpha]_{\mathrm{D}}^{20}=$ -360.0 (c 0.77, DMSO); ${ }^{1} \mathrm{H}$ NMR (400 MHz, DMSO- $d_{6}$ ): 8.46 (d, $J$ $=7.9,1 \mathrm{H}, \mathrm{NH}), 8.32(\mathrm{~s}, 1 \mathrm{H}, \mathrm{H}-2), 8.10(\mathrm{~s}, 1 \mathrm{H}, \mathrm{H}-5), 7.81(\mathrm{~d}, J=$ 15.6, $\left.1 \mathrm{H}, \mathrm{H}_{\beta}\right), 7.42-7.40(\mathrm{~m}, 2 \mathrm{H}, \mathrm{Ph}), 7.34-7.30(\mathrm{~m}, 2 \mathrm{H}, \mathrm{Ph})$, $7.24-7.20(\mathrm{~m}, 1 \mathrm{H}, \mathrm{Ph}), 6.31\left(\mathrm{~d}, J=15.6,1 \mathrm{H}, \mathrm{H}_{\beta}\right), 5.54-5.47(\mathrm{~m}$, $1 \mathrm{H}, \mathrm{CH}), 4.29-4.26\left(\mathrm{~m}, 2 \mathrm{H}, \mathrm{CH}_{2}\right), 3.61-3.58\left(\mathrm{~m}, 2 \mathrm{H}, \mathrm{CH}_{2}\right), 3.29$ $\left(\mathrm{s}, 3 \mathrm{H}, \mathrm{CH}_{3}\right), 1.55$ (d, $\left.J=7.0,3 \mathrm{H}, \mathrm{CH}_{3}\right) ;{ }^{13} \mathrm{C} \mathrm{NMR}(100 \mathrm{MHz}$, DMSO- $\left.d_{6}\right)$ : $166.1,165.5,156.0,155.4,144.3,137.6,133.4,128.3$ (2C), 126.7, 126.1 (2C), 125.3, 118.3, 116.6, 69.8, 63.4, 58.1, 49.1, 22.3; IR ( $\mathrm{cm}^{-1}$ ): 3357 (w, br), 2976 (w, br), 1710 (m), 1574 (s), 1506 (m), 1265 (s), 1166 (s), 1034 (m), 964 (m), 732 (s), 698 (s); HRMS (ASAP $\left.{ }^{+}, m / z\right)$ : found 384.1379 , calcd for $\mathrm{C}_{20} \mathrm{H}_{22} \mathrm{~N}_{3} \mathrm{O}_{3} \mathrm{~S}$ $[\mathrm{M}+\mathrm{H}]^{+} 384.1382$.

\section{Synthesis of 2-hydroxyethyl (R,E)-3-(4-((1-phenylethyl)amino)-} thieno[2,3- $d]$ pyrimidin-6-yl)acrylate (6)

Compound 6 was prepared as described for $\mathbf{5}$, but starting with (R)-6-bromo- $N$-(1-phenylethyl)thieno[2,3- $d$ ]-pyrimidin-4-amine (1) 2-hydroxyethyl acrylate $(0.69 \mathrm{~mL}, 6.01 \mathrm{mmol})$. The crude product (139 mg) was purified by a silica-gel column chromatography (ethyl acetate, $\left.R_{\mathrm{f}}=0.35\right)$ giving $103 \mathrm{mg}(0.28 \mathrm{mmol}$, $47 \%$ ) as a light yellow solid; mp $144-145^{\circ} \mathrm{C}$; purity (HPLC): $92 \%$, $t_{\mathrm{R}}=19.4 \mathrm{~min} ;[\alpha]_{\mathrm{D}}^{20}=-362.9$ (c 1.01, DMSO). ${ }^{1} \mathrm{H}$ NMR $(400$ MHz, DMSO- $\left.d_{6}\right): 8.46(\mathrm{~d}, J=7.9,1 \mathrm{H}, \mathrm{NH}), 8.32(\mathrm{~s}, 1 \mathrm{H}, \mathrm{H}-2), 8.09$ (s, $1 \mathrm{H}, \mathrm{H}-5), 7.81$ (d, $\left.J=15.6,1 \mathrm{H}, \mathrm{H}_{\beta}\right), 7.42-7.41(\mathrm{~m}, 2 \mathrm{H}, \mathrm{Ph})$, 7.33-7.30 (m, 2H, Ph), 7.23-7.21 (m, 1H, Ph), 6.30 (d, J=15.6, $\left.1 \mathrm{H}, \mathrm{H}_{\alpha}\right), 5.53-5.48(\mathrm{~m}, 1 \mathrm{H}, \mathrm{CH}), 4.88-4.86(\mathrm{~m}, 1 \mathrm{H}, \mathrm{OH}), 4.17(\mathrm{t}, J$ $\left.=4.8,2 \mathrm{H}, \mathrm{CH}_{2}\right), 3.63\left(\mathrm{q}, J=4.8,2 \mathrm{H}, \mathrm{CH}_{2}\right), 1.56-1.55(\mathrm{~d}, J=7.0$, $\left.3 \mathrm{H}, \mathrm{CH}_{3}\right) ;{ }^{13} \mathrm{C}$ NMR (100 MHz, DMSO- $\left.d_{6}\right)$ : $166.6,165.6,156.0$, 
155.3, 144.3, 137.3, 133.5, 128.3 (2C), 126.7, 126.1 (2C), 125.2, 118.6, 116.7, 66.1, 59.0, 49.1, 22.3; IR ( $\mathrm{cm}^{-1}$ ): 3485 (w, br), 3422 (w, br), 3244 (w, br), 2357 (w), 1678 (m), 1619 (m), 1583 (s), 1540 (m), $1509(\mathrm{~m}), 1454(\mathrm{~m}), 1281(\mathrm{~m}), 1178(\mathrm{~s}), 1066(\mathrm{~m}), 844(\mathrm{~s}), 695$ (m); HRMS $\left(\mathrm{ASAP}^{+}, \mathrm{m} / z\right)$ : found 370.1226 , calcd for $\mathrm{C}_{19} \mathrm{H}_{20} \mathrm{~N}_{3} \mathrm{O}_{3} \mathrm{~S}$ $[\mathrm{M}+\mathrm{H}]^{+} 370.1225$.

\section{Synthesis of $(R, E)-3-(4-((1-p h e n y l e t h y l)$ amino $)$ thieno[2,3- $d]$ pyrimidin-6-yl)acrylamide (7)}

Methyl ( $R, E)-3-(4-((1-$ phenylethyl)amino)thieno[2,3- $d]$ pyrimidin6-yl)acrylate (2) (202 mg, $0.597 \mathrm{mmol})$ was added to a pressure tube and dissolved in $25 \%$ aq. ammonia $(15 \mathrm{~mL}, 200 \mathrm{mmol})$ and THF ( $4 \mathrm{~mL}$ ), and stirred at $30{ }^{\circ} \mathrm{C}$ for $96 \mathrm{~h}$. The product was extracted with $\mathrm{CH}_{2} \mathrm{Cl}_{2}(3 \times 15 \mathrm{~mL})$ and dried with brine $(10 \mathrm{~mL})$ and then over anhydrous $\mathrm{Na}_{2} \mathrm{SO}_{4}$. After concentration, the crude product $(102 \mathrm{mg})$ was crystallized from acetonitrile $(7 \mathrm{~mL})$ resulting in $30 \mathrm{mg}(0.093 \mathrm{mmol}, 16 \%)$ of white needle crystals; mp 246-251 ${ }^{\circ} \mathrm{C}$ (decomp.); purity (HPLC): 98\%, $t_{\mathrm{R}}=17.3 \mathrm{~min}$; $[\alpha]_{\mathrm{D}}^{20}=-396.7$ (c 0.97, DMSO). ${ }^{1} \mathrm{H}$ NMR (400 MHz, DMSO- $d_{6}$ ): $8.40(\mathrm{~d}, J=7.8,1 \mathrm{H}, \mathrm{NH}), 8.29$ (s, 1H, H-2), 7.95 (s, 1H, H-5), 7.62 (s, 1H, NH), $7.54\left(\mathrm{~d}, J=15.4,1 \mathrm{H}, \mathrm{H}_{\beta}\right), 7.42-7.40(\mathrm{~m}, 2 \mathrm{H}, \mathrm{Ph})$, 7.34-7.30 (m, 2H, Ph), 7.24-7.20 (m, 1H, Ph), 7.20 (s, 1H, NH), $6.41\left(\mathrm{~d}, J=15.4,1 \mathrm{H}, \mathrm{H}_{\alpha}\right), 5.54-5.47(\mathrm{~m}, 1 \mathrm{H}, \mathrm{CH}), 1.55(\mathrm{~d}, J=7.0$, $\left.3 \mathrm{H}, \mathrm{CH}_{3}\right) ;{ }^{13} \mathrm{C}$ NMR $\left(100 \mathrm{MHz}\right.$, DMSO- $\left.d_{6}\right): 167.4,165.8,155.8$, 154.9, 144.5, 134.7, 132.2, 128.3 (2C), 126.7, 126.1 (2C), 123.5, 123.2, 116.7, 49.1, 22.4; IR ( $\left.\mathrm{cm}^{-1}\right): 3447$ (m), 3276 (m, br), 3071 (w, br), 1667 (s), 1587 (m), 1573 (m), 1499 (m), 1309 (s), 1106 (m), $950(\mathrm{~s}), 777(\mathrm{~m}), 697(\mathrm{~m})$; HRMS $\left(\mathrm{ASAP}^{+}, \mathrm{m} / \mathrm{z}\right)$ : found 325.1121, calcd for $\mathrm{C}_{17} \mathrm{H}_{17} \mathrm{~N}_{4} \mathrm{OS}[\mathrm{M}+\mathrm{H}]^{+}$325.1123.

\section{Synthesis of $(R, E)-N, N$-dimethyl-3-(4-((1-phenylethyl)amino) thieno-[2,3-d]pyrimidin-6-yl)acrylamide (8)}

Compound 8 was prepared as described for 5, but reacting $(R)-6$ bromo- $N$-(1-phenylethyl)thieno[2,3- $d]$-pyrimidin-4-amine with $N, N$-dimethylacrylamide. The crude product (381 mg) was first purified by silica-gel column chromatography (tetrahydrofuran/n-pentane, $2 / 3)$ yielded $\mathbf{8}(234 \mathrm{mg})$ as a light yellow oil. The oil solidified upon addition of diethyl ether followed by evaporation. The material was dissolved in hot $\mathrm{CH}_{2} \mathrm{Cl}_{2}(8 \mathrm{~mL})$ and crystallised by cooling giving $57 \mathrm{mg}(0.16 \mathrm{mmol}, 27 \%)$ of a white solid; mp $154-155^{\circ} \mathrm{C}$; purity (HPLC): $99 \%, t_{\mathrm{R}}=19.1 \mathrm{~min} ;[\alpha]_{\mathrm{D}}^{20}=$ -396.6 (c 1.01, DMSO). ${ }^{1} \mathrm{H}$ NMR (400 MHz, DMSO- $d_{6}$ ): 8.37 (d, $J=7.9,1 \mathrm{H}, \mathrm{NH}), 8.29(\mathrm{~s}, 1 \mathrm{H}, \mathrm{H}-2), 7.97(\mathrm{~s}, 1 \mathrm{H}, \mathrm{H}-5), 7.60(\mathrm{~d}, J=$ 15.0, $\left.1 \mathrm{H}, \mathrm{H}_{\beta}\right), 7.42-7.40(\mathrm{~m}, 2 \mathrm{H}, \mathrm{Ph}), 7.34-7.30(\mathrm{~m}, 2 \mathrm{H}, \mathrm{Ph})$, $7.24-7.20(\mathrm{~m}, 1 \mathrm{H}, \mathrm{Ph}), 6.88\left(\mathrm{~d}, J=15.0,1 \mathrm{H}, \mathrm{H}_{\alpha}\right), 5.54-5.47(\mathrm{~m}$, $1 \mathrm{H}, \mathrm{CH}), 3.14\left(\mathrm{~s}, 3 \mathrm{H}, \mathrm{CH}_{3}\right), 2.94\left(\mathrm{~s}, 3 \mathrm{H}, \mathrm{CH}_{3}\right), 1.55(\mathrm{~d}, J=7.0,3 \mathrm{H}$, $\left.\mathrm{CH}_{3}\right) ;{ }^{13} \mathrm{C}$ NMR (100 MHz, DMSO- $\left.d_{6}\right): 166.2,164.7,155.9,154.9$, 144.5, 134.9, 133.9, 128.3 (2C), 126.7, 126.1 (2C), 123.3, 119.5, 116.6, 49.1, 36.9, 35.4, 22.4; IR ( $\left.\mathrm{cm}^{-1}\right): 3262$ (w, br), $1644(\mathrm{~m})$, 1574 (s), 1506 (m), 1305 (m), 1263 (m), 1137 (m), 1104 (m), 688 (m), $557(\mathrm{~m})$; HRMS (ASAP $\left.{ }^{+}, \mathrm{m} / \mathrm{z}\right)$ : found 353.1431, calculated for $\mathrm{C}_{19} \mathrm{H}_{21} \mathrm{~N}_{4} \mathrm{OS}[\mathrm{M}+\mathrm{H}]^{+}$353.1431.

\section{In vitro EGFR (ErbB1) inhibitory potency}

The compounds were supplied in a $10 \mathrm{mM}$ DMSO solution, and enzymatic EGFR (ErbB1) inhibition potency was determined by
Invitrogen (LifeTechnology) using their $\mathrm{Z}^{\prime}$-LYTE® assay technology. ${ }^{32}$ All compounds were first tested for their inhibitory activity at $100 \mathrm{nM}$ in duplicates. The potency observed at $100 \mathrm{nM}$ was used to set starting point of the $\mathrm{IC}_{50}$ titration cure, in which three levels were used 100, 1000 or $10000 \mathrm{nM}$. The $\mathrm{IC}_{50}$ values reported are based on the average of at least 2 titration curves (minimum 20 data points), and were calculated from activity data with a four parameter logistic model using SigmaPlot (Windows Version 12.0 from Systat Software, Inc.). Unless stated otherwise the ATP concentration used was equal to $K_{\mathrm{M}}$. The average standard deviation for single point measurements were $<4 \%$. The inhibitory potency towards EGFR mutants was determined in the same way.

\section{Molecular modelling}

The X-ray crystal structures of the protein 2J6M (Wild-type EGFR) were prepared using the protein preparation wizard, which is part of the Maestro software package (Schrödinger Release 2016-4: Glide, Schrödinger, LLC, New York, NY, 2016). Bond orders and formal charges were added for het-groups, and hydrogens were added to all atoms in the system. Water molecules beyond $5 \AA$ from het-groups were removed. To alleviate steric clashes that may exist in the original PDB structures, an all-atom constrained minimization was carried out using the OPLS-3 force field. The minimization was terminated when the energy converged or the RMSD reached a maximum cutoff of $0.30 \AA$. The resulting protein structures were used in the following docking study. Ligands were drawn using the $2 \mathrm{D}$ sketcher within the Maestro package and were prepared using LigPrep (LigPrep, v2.2; Schrödinger, LLC). For the computational investigation of the receptor-inhibitor structures, the energy minimized structures of $2 \mathrm{~J} 6 \mathrm{M}$ and ligands were subsequently docked using Glide (Schrödinger Release 2016-4: Glide, Schrödinger, LLC, New York, NY, 2016). Selected low-energy protein-ligand poses were carried forward for $10 \mathrm{~ns}$ dynamic simulations. For dynamic simulation, the best poses from docking were used as starting points when building the model systems. Dynamic simulations were conducted for $10 \mathrm{~ns}$ simulation time using Maestros Desmond suite ${ }^{33}$ the OPLS-3 force field and a TIP4P solvent model. Briefly, this was performed by putting the docked protein-ligand complex inside a minimized solvent box and adding ions $\left(\mathrm{Na}^{+}\right.$or $\left.\mathrm{Cl}^{-}\right)$in order to have an electrical neutral system. Finally, $\mathrm{NaCl}$ was added to a total concentration of $0.15 \mathrm{M}$, which is approximately the physiological concentration of monovalent ions. This gave normally a system of approximately 39000 atoms. Molecular dynamics were then calculated on these systems using the isothermalisobaric (NPT) ensemble at $300 \mathrm{~K}$ and 1.01325 bar. Trajectory analysis were performed using Desmond's Simulation Interactions Diagram tool and all the graphical pictures were made using Maestro.

\section{Kinase panel}

The compounds were supplied in a $10 \mathrm{mM}$ DMSO solution, and enzymatic kinase inhibition potency was determined by Invitrogen (LifeTechnology) using their Z'-LYTE® assay 
technology, ${ }^{32}$ at $500 \mathrm{nM}$ in duplicates. ATP concentration used was equal to $K_{\mathrm{M}}$, except when this service was not provided and other concentrations had to be used.

\section{Conclusions}

Undesirable physical-chemical properties can prohibit development of potent molecules to drugs. In the thienopyrimidine series of EGFR inhibitors, the 6-phenyl group does not contribute much to activity, but rather acts as a framework for grafting other activity inducing substituent. Thus, finding substitutes for the phenyl core is highly desirable. It was envisioned that substituted alkenes could be employed in this regard, which triggered a study of the Heck reaction. Palladium catalysed couplings between (R)-6-bromo- $N$-(1-phenylethyl) thieno[2,3- $d]$ pyrimidin-4-amine and various acrylates were highly dependent on all parameters evaluated in line with past observations. Bis(tri-tert-butylphosphine)palladium(0) was found to be the most suited catalyst with $N, N$-dimethylacetamide as reaction medium. Other solvents could also be used, but conversion rate is lowered when substituting $\mathrm{N}, \mathrm{N}$-dicyclohexylmethylamine as base or excluding tetrabutylammonium chloride as additive. The conversion rate was also affected by acrylate structure and reaction with acrylamide was prohibited. The different reactions conditions gave a variable trans/cis ratio of product. However, the major challenge was that the products undergo a light induced trans-cis isomerization, which complicates purification and lower yield of the trans product. The products were however stable in the dark, allowing for bioevaluation of these compounds. Profiling towards EGFR and a panel of 50 kinases indicate that acrylate substituents grafted on thieno[2,3- $d]$ pyrimidines is an attractive scaffold for identification of potent and highly selective EGFR inhibitors. These leads also possess promising physical chemical properties. Provided a way is found to make these structures configurational stable, highly efficient EGFR inhibitors could be developed.

\section{Acknowledgements}

Susana Villa Gonzalez is thanked for the HRMS experiments, and Roger Aarvik are acknowledged for technical support. Anders Jahres Foundation is thanked for financial support.

\section{Notes and references}

1 W. Pao and J. Chmielecki, Nat. Rev. Cancer, 2010, 10, 760774.

2 M. R. Brewer, C. H. Yun, D. Lai, M. A. Lemmon, M. J. Eck and W. Pao, Proc. Natl. Acad. Sci. U. S. A., 2013, 110, E3595-E3604.

3 H. J. Lee, A. N. Seo, E. J. Kim, M. H. Jang, Y. J. Kim, J. H. Kim, S. W. Kim, H. S. Ryu, I. A. Park, S. A. Im, G. Gong, K. H. Jung, H. J. Kim and S. Y. Park, Br. J. Cancer, 2015, 112, 103-111.

4 N. Cook, K. K. Frese and M. Moore, Gastrointest. Cancer: Targets Ther., 2014, 4, 23-37.

5 S. N. Li and H. Q. Li, Expert Opin. Ther. Pat., 2014, 24, 309321.
6 Y. J. Liu, C. M. Zhang and Z. P. Liu, Anti-Cancer Agents Med. Chem., 2012, 12, 391-406.

7 P. Traxler, P. R. Allegrini, R. Brandt, J. Brueggen, R. Cozens, D. Fabbro, K. Grosios, H. A. Lane, P. McSheehy, J. Mestan, T. Meyer, C. Tang, M. Wartmann, J. Wood and G. Caravatti, Cancer Res., 2004, 64, 4931-4941.

8 Y. W. Park, M. N. Younes, S. A. Jasser, O. G. Yigitbasi, G. Zhou, C. D. Bucana, B. N. Bekele and J. N. Myers, Clin. Cancer Res., 2005, 11, 1963-1973.

9 P. LoRusso, K. Venkatakrishnan, E. G. Chiorean, D. Noe, J. T. Wu, S. Sankoh, M. Corvez and E. A. Sausville, Invest. New Drugs, 2014, 32, 160-170.

10 T. Doi, H. Takiuchi, A. Ohtsu, N. Fuse, M. Goto, M. Yoshida, N. Dote, Y. Kuze, F. Jinno, M. Fujimoto, T. Takubo, N. Nakayama and R. Tsutsumi, Br. J. Cancer, 2012, 106, 666-672.

11 J. Han, S. Henriksen, K. G. Nørsett, E. Sundby and B. H. Hoff, Eur. J. Med. Chem., 2016, 124, 583-607.

12 Y. H. Peng, H. Y. Shiao, C. H. Tu, P. M. Liu, J. T.-A. Hsu, P. K. Amancha, J. S. Wu, M. S. Coumar, C. H. Chen, S. Y. Wang, W. H. Lin, H. Y. Sun, Y. S. Chao, P. C. Lyu, H. P. Hsieh and S. Y. Wu, J. Med. Chem., 2013, 56, 3889-3903.

13 J. Han, S. J. Kaspersen, S. Nervik, K. G. Nørsett, E. Sundby and B. H. Hoff, Eur. J. Med. Chem., 2016, 119, 2778-2799.

14 S. Bugge, A. F. Buene, N. Jurisch-Yaksi, I. U. Moen, E. M. Skjoensfjell, E. Sundby and B. H. Hoff, Eur. J. Med. Chem., 2016, 107, 255-274.

15 T. Beckers, A. Sellmer, E. Eichhorn, H. Pongratz, C. Schaechtele, F. Totzke, G. Kelter, R. Krumbach, H. H. Fiebig, F. D. Boehmer and S. Mahboobi, Bioorg. Med. Chem., 2012, 20, 125-136.

16 S. Bugge, S. J. Kaspersen, S. Larsen, U. Nonstad, G. Bjørkøy, E. Sundby and B. H. Hoff, Eur. J. Med. Chem., 2014, 75, 354374.

17 N. A. Meanwell, Chem. Res. Toxicol., 2011, 24, 1420-1456.

18 I. P. Beletskaya and A. V. Cheprakov, Chem. Rev., 2000, 100, 3009-3066.

19 S. Bugge, I. U. Moen, K. O. Kragseth Sylte, E. Sundby and B. H. Hoff, Eur. J. Med. Chem., 2015, 94, 175-194.

20 P. M. Murray, J. F. Bower, D. K. Cox, E. K. Galbraith, J. S. Parker and J. B. Sweeney, Org. Process Res. Dev., 2013, 17, 397-405.

21 C. Amatore and A. Jutand, Acc. Chem. Res., 2000, 33, 314-321. 22 C. Amatore and A. Jutand, J. Organomet. Chem., 1999, 576, 254-278.

23 C. S. Consorti, F. R. Flores and J. Dupont, J. Am. Chem. Soc., 2005, 127, 12054-12065.

24 M. T. Reetz and J. G. de Vries, Chem. Commun., 2004, 15591563.

25 E. Amadio, A. Scrivanti, M. Bortoluzzi, M. Bertoldini, V. Beghetto, U. Matteoli and G. Chessa, Inorg. Chim. Acta, 2013, 405, 188-195.

26 M. B. Ibrahim, R. Suleiman, M. Fettouhi and B. El Ali, Transition Met. Chem. (Dordrecht, Neth.), 2017, 42, 1-8.

27 H. Wu, C. Jin, G. L. Huang, L. J. Wang, J. L. Jiang and L. Y. Wang, Sci. China: Chem., 2011, 54, 951-956. 
28 F. Dehghani Firuzabadi, Z. Asadi and F. Panahi, RSC Adv., 2016, 6, 101061-101070.

29 S. Jadhav, A. Jagdale, S. Kamble, A. Kumbhar and R. Salunkhe, RSC Adv., 2016, 6, 3406-3420.

30 N. Nishiwaki, S. Hamada, T. Watanabe, S. Hirao, J. Sawayama, H. Asahara, K. Saigo, T. Kamata and M. Funabashi, $R S C A d v .$, 2015, 5, 4463-4467.
31 P. Knesl, D. Roeseling and U. Jordis, Molecules, 2006, 11, 286-297.

32 B. A. Pollok, B. D. Hamman, S. M. Rodems and L. R. Makings, Optical probes and assays, WO 2000066766 A1, 2000.

33 v. Desmond Molecular Dynamics System, D. E. Shaw Research, Maestro-Desmond Interoperability Tools, version 3.9, Schrödinger, New York, NY, 2014. 